\title{
KARAKTERISASI ASAL-USUL DAN TINGKAT KEMATANGAN BIOMARKA MINYAK MENTAH TARAKAN-KALIMANTAN UTARA
}

\author{
Eduardus Edi \\ Universitas Timor \\ Email: edieduardus@gmail.com
}

\begin{abstract}
ABSTRAK
Karakteristik geokimia organik (biomarker) memberikan informasi tentang asal usul, lingkungan pengendapan dan kematangan minyak. Karekterisasi Minyak mentah diekstrak dengan pelarut $n$-heksan dengan perbandingan n-heksan: minyak mentah (50: 2) selama 24 jam untuk memisahkan asphaltene dari minyak mentah. jika endapan tidak terpisah dengan sempurna maka disentrifugasi dengan kecepatan $2400 \mathrm{rpm}$ dalam waktu 20 menit. Hasil ekstrak minyak mentah murni difraksinasi dengan menggunakan kromatografi kolom metode McCharty. Hasil ekstrak dari pengoloman diperoleh fraksi netral, fraksi asam dan fraksi polar. Fraksi netral dipisahkan dengan metode KLTP dan ekstrak difraksinasi menjadi komponen hidrokarbon yang terdiri dari fraksi alifatik dan fraksi aromatik, selanjutnya dianalisis fraksi aromatik dengan GCMS. Hasil analisis GCMS pada fraksi aromatik diperoleh senyawa alkil benzene, naftalena, fenanterna dan kadelan, senyawa -senyawa yang diperoleh dianggap sebagai informasi turunan dari produk alami tanaman tingkat tinggi, bakteri, penanda asal usul lingkungan pengendapan dan kematangan minyak.
\end{abstract}

Kata kunci - Biomarka, Juwata, minyak mentah, GCMS.

\begin{abstract}
Characteristic of organic geochemistry (biomarker) gives information about environment of crude oil. Crude oil was extracted by n-heksan:crude oil (50:2) for $24 \mathrm{~h}$ to separate the crude oil with asphaltene. if precipitation does not separate completely the centrifuge $2400 \mathrm{rpm}$ within 20 minutes. Extract was obtained then fractionated by its polarity using column chromatography McCharty method.Subsequently, it was extracted to obtain neutral, acid and polar fractions. Neutral fraction was separated by KLTP methode and the extract were fractionated into hydrocarbon component which consist of Aliphatic and Aromatic compounds. The obtaining compounds were characterized by GCMS. Result of GCMS analyzed in Aliphatic fraction shown presence of n-alkane, trissiklik terpenoid, hopan and bikadinas.These compounds are considered as important derivatives from natural products of higher plants of bacteria, depositional environment and determine the maturity level of oil.
\end{abstract}

Keyword - Biomarker, Juwata, Crude oil, GCMS. 


\section{Pendahuluan}

Minyak bumi merupakan sumber energi yang vital, tidak dapat diperbaharui dan memiliki nilai ekonomis yang sangat tinggi, banyak digunakan untuk industri, transportasi, rumah tangga, dan merupakan sumber devisa bagi negara. Kebutuhan terhadap energi minyak bumi tiap tahun mengalami peningkatan yang tidak diimbangi dengan peningkatan produksinya menyebabkan Indonesia terancam krisis energy dan harus mengimpor 20\%-30\% dari luar negeris. Oleh karena itu, perlu dilakukan upaya eksplorasi untuk mencari sumber minyak baru sehingga ancaman krisis energi dapat teratasi (Ilham, 2014).

Proses eksplorasi menghasilkan minyak mentah (crude oil) berbeda-beda pada setiap lapangan atau sumur, maka perlu dilakukan karakterisasi. (Purwono, 2008). Karakterisasi geokimia organik dilakukan berdasarkan perilaku senyawa biomarka. Keberadaan senyawa biomarka ini memberikan informasi mengenai molekul kompleks yang terjadi dalam batuan sumber (source rocks), dimana biomarka tersebut berasal dari prekursor senyawa organik yang terkandung dalam berbagai organisme hidup. Senyawa tersebut memberikan informasi mengenai asal usul bahan organik, lingkungan pengendapan dan kematangan minyak. Asal-usul bahan organik tersebut diselidiki berdasarkan senyawa prekursor biologi. Hasil penelusuran senyawa perkursor biologi maka dapat juga diinformasikan mengenai gambaran proses geokimia yang berlangsung pada sedimen dalam berbagai tahap pematangan . Adapun beberapa biomarka yang menggambarkan tujuan dari karakterisasi geokimia organik yaitu pentasiklik triterpena digunakan sebagai parameter kematangan termal, asam karboksilat untuk menentukan adanya biodegradasi dengan jumlah $\mathrm{C}_{12}-\mathrm{C}_{20}$, asiklik bifitan dan siklik biftan digunakan untuk menentukan lingkungan pengendapan terdekteksi pada puncak kromatogram dengan $\mathrm{m} / \mathrm{z} 57$ dan n-alkana digunakan sebagai penunjuk geologi sumber bahan organik dengan jumlah atom $\mathrm{C}<20$ berasal dari organism laut dan $C>20$ sebagai penanda untuk tanaman testerial (Yuanita, 2007)

Juwata merupakan salah satu ladang minyak bumi dari sub- Cekungan Tarakan, secara geografis terletak sekitar $240 \mathrm{Km}$ arah Utara-sampai timur laut dari Balikpapan (Yoga, 2014) . Pengeksplorasian minyak bumi pada sumur Juwata Tarakan Kalimantan oleh PT Pertamina unit V Tarakan telah melalui penyelidikan awal antara lain menyangkut survei geologi dan geofisika. Penyelidikan geokimia organik yang merupakan parameter baru belum dilakukan sehingga informasi mengenai komposisi bahan organik, asal-usulnya serta tingkat kematangan minyak belum bisa dilaporkan untuk menunjang proses pengeksplorasian selanjutnya. Oleh karena itu, perlu dilakukan karakterisasi geokimia organik melalui profil senyawa biomarka untuk mengetahui kematangan minyak, asal-usul bahan organik, lingkungan pengendapan dan kematangan minyak.

\section{Tinjauan Pustaka}

2.1 Tinjauan Geologi Sampel

Sumur minyak mentah Juwata pulau Tarakan secara administratif terletak di Kalimantan Utara kota Tarakan dan secara geografi terletak pada koordinat $3^{0} 22^{\prime} 25,2^{\prime \prime}$ LU $117^{0} 34^{\prime} 23,2$ "' BT pada sub cekungan Tarakan (Gambar 2.1). Cekungan Tarakan merupakan salah satu dari tiga cekungan tersier utama yang terdapat di bagian timur continental margin Kalimantan (dari utara ke selatan: Cekungan Tarakan, Cekungan Kutai dan Cekungan Barito), yang dicirikan dengan hadirnya batuan sedimen klastik sebagai penyusunnya yang dominan dari ukuran halus hingga kasar dengan beberapa endapan karbonat (Hidayati, 2007).

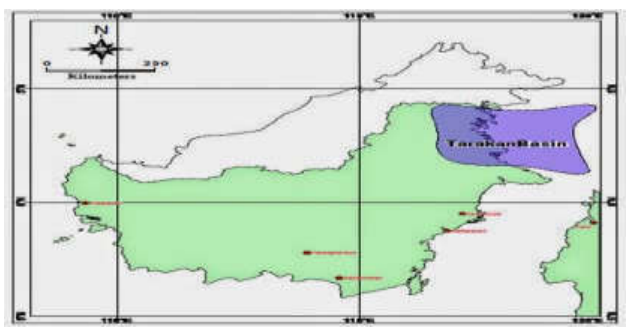

Gambar 2.1 Cekungan Tarakan

ISSN Print $\quad: 1979-7141$ 
Secara fisiografis, Cekungan Tarakan berada pada bagian utara dari Pulau Kalimantan yang luasnya mencapai $68.000 \mathrm{~km} 2$.Cekungan Tarakan meliputi kawasan daratan dan sebagiannya lagi kawasan lepas pantai.Di bagian utara dibatasi oleh tinggian Samporna yang terletak sedikit di utara perbatasan Indonesia-Malaysia, di sebelah selatan oleh Punggungan Mangkalihat yang memisahkan Cekungan Tarakan dan Cekungan Kutai. Ke arah barat dari cekungan meliputi kawasan daratan sejauh 60 sampai $100 \mathrm{~km}$ dari tepi pantai hingga Tinggian Kuching, ke bagian timur batas cekungannya diketahui melewati kawasan paparan benua dari Laut Sulawesi.

Proses pengendapan Cekungan Tarakan dimulai dari proses pengangkatan. Transgresi yang diperkirakan terjadi pada Kala Eosen sampai Miosen awal bersamaan dengan pengangkatan gradual pada Tinggian Kuching dari barat ke timur. Pada kala Miosen tengah terjadi penurunan (regresi) pada Cekungan Tarakan, yang dilanjutkan dengan terjadinya pengendapan progradasi ke arah timur dan membentuk endapan delta, yang menutupi endapan prodelta dan batial. Cekungan Tarakan mengalami proses penurunan secara lebih aktif lagi pada Kala Miosen sampai Pliosen. Proses sedimentasi delta yang tebal relatif bergerak ke arah timur terus berlanjut selaras dengan waktu (Ellen, 2008).

\subsection{Minyak Bumi}

Minyak bumi berasal dari pelapukan sisa-sisa organisme sehinggga disebut bahan bakar fosil.Minyak bumi berasal dari jasad renik lautan, tumbuhan dan hewan Sisa- sisa organisme itu mengendap kemudian ditutupi oleh lumpur.Lapisan lumpur tersebut lambat laun berubah menjadi batuan karena pengaruh suhu dan tekanan lapisan di atasnya.Sementara itu, dengan meningkatnya tekanan dan suhu, bakteri anaerob menguraikan sisa-sisa jasad renik itu dan mengubahnya menjadi minyak dan gas. Proses pembentukan minyak dan gas ini memakan waktu jutaan tahun (Harish, 2014). Minyak bumi merupakan senyawa yang kompleks terdiri dari ikatan atom Hidrogen $(\mathrm{H})$ dan Karbon $(\mathrm{C})$ dengan beberapa variasi yang terbentuk secara alamiah dari ekstraksi material organik (kerogen) yang terpengaruh oleh suhu dan tekanan. Minyak mentah (crude oil) pada umumnya tersusun oleh senyawa hidrokarbon yang lebih kompleks dari pada gas (Yusriani, 2009).

\subsection{Biomarka}

Biomarka merupakan fosil molekul yakni senyawa yang berasal dari organisme yang hidup pada zaman dahulu yang terdiri dari karbon, hidrogen dan unsur-unsur lainnya. Senyawa tersebut dapat mengalami perubahan gugus fungsi selama proses diagenesis maupun katagenesis, namun kerangka karbonnya masih tersimpan secara utuh sehingga bisa ditelusuri asal-usulnya (Peters dan Moldowan, 1993).

Biomarka merupakan penanda biota yang ditemukan dalam sedimen, minyak bumi, maupun batubara. Keberadaan suatu biota dapat diketahui dari molekul atau senyawa yang mengalami proses deposisi selama proses sedimentasi. Proses deposisi dapat terjadi akibat proses biologis dari bakteri pengurai dan juga proses geologi seperti tekanan dan suhu yang menghasilkan berbagai jenis biomarker dan sumbernya seperti pada Tabel 2.1. Senyawa biomarka dapat digunakan untuk menentukan organisme yang terlibat selama proses sedimentasi serta kondisi lingkungan deposisi. Sumber bahan organik dari senyawa biomarka dapat berasal dari bakteri maupun tanaman tingkat tinggi (Killops dan Killops, 1993 ; Tissot dan Welte, 1984) 
Tabel 2.1.Kelas penting biomarker dan sumber (Waples \&Machihara, 1985)

\begin{tabular}{|l|c|}
\hline \multicolumn{1}{|c|}{ BIOMARKA } & SUMBER \\
\hline Normal alkana $(>\mathrm{C} 22)$ & Lilin tumbuhan darat \\
\hline Normal alakana $(<\mathrm{C} 22)$ & Lipid Alga \\
\hline Isoprenoid $(<\mathrm{C} 20)$ & Berbagai macam klorofil \\
\hline Isoprenoid $(>\mathrm{C} 20)$ & Lipid atau klorofil dari alga hipersalin \\
\hline \multicolumn{1}{|c|}{ Triterpana } & Triterpenoid bakteri \\
\hline
\end{tabular}

\section{Metode Penelitian}

\subsection{Alat}

Peralatan yang digunakan dalam penelitian ini adalahseperangkat peralatan soxhlet extractor, seperangkat alat distilasi fraksinasi, seperangkat alat kromatografi kolom, seperangkat alat rotary evaporator, gelas piala, corong tulip, gelas ukur, cawan, spatula, botol vial, pipet tetes, pipet Pasteur, neraca analitik, oven, chamber Kromatografi Lapis Tipis (KLT), seperangkat alat Gas Chromatography (GC) yang digabung dengan Spektroskopi Massa (MS)Agilent 5890.

\subsection{Bahan}

Bahan-bahan yang digunakan antara lain sampel minyak mentah Juwata Tarakan, Kalimantan Utara, gas nitrogen, kertas saring, alumunium foil, kapas, gunting, seasand, silika gel $\mathrm{GF}_{254}$ untuk kromatografi kolom, aquabides, cellite, 1,2,5,6-dibenzantrasena (DBA) sebagai senyawa pembanding, dan beberapa pelarut organik yaitu n-heksana p.a, diklorometan p.a, aseton p.a, kloroform p.a, metanol p.a, dietileter p.a, etil asetat p.a.

\subsection{Fraksinasi}

Sampel minyak mentah diambil dari sumur dengan menggunakan mangkuk kaca dan dimasukan dalam botol kaca.Sampel minyak mentah yang diambil terdiri dari dual lapisan yaitu lapisan air dan minyak,lapisan minyak terlebih dahulu dipisahkan dari air dengan menggunakan corong pisah.Sampel minyak yang bebas air dilarutkan dengan menggunakan pelarut n-heksan dengan perbandingan v:v (50:2) selama 24 jam untuk memisahkan aspalten dan minyak. Apabila hasil endapan tidak sempurna maka dilakukan sentrifugas dengan kecepatan $2400 \mathrm{rpm}$ dalam waktu 20 menit untuk mendapatkan ekstrak minyak. Hasil ekstraksi diuapkan pelarutnya menggunakan rotary evaporator vakum lalu dipindahkan dalam botol vial. Ekstrak kering tersebut ditimbang dan disimpan untuk analisis selanjutnya (Farhaduzzaman dkk, 2012)

\subsection{Pemisahan Ekstrak Minyak Mentah}

Fraksinasi dilakukan menggunakan metode kromatografi kolom Silika Gel $\mathrm{GF}_{254}$ yang telah diimpregnasi dengan $\mathrm{KOH}$ dalam IPA sebagai fasa diam dan beberapa pelarut organik sebagai fasa gerak. Pencampuran dilakukan di dalam labu evaporator, kemudian pelarutnya diuapkan. Proses pembuatan kolom dilakukan sebagai berikut: langkah pertama yang dilakukan adalah memasukan kapas sebagai dasar dari lapisan kolom lalu diikuti oleh seasand. Setelah terbentuk dua lapis, kolom diisi dengan dietileter lalu diikuti dengan Silika Gel $\mathrm{GF}_{254}$ yang telah diimpregnasi sebelumnya. Langkah selanjutnya adalah ditambahkan seasand sebagai lapisan akhir hingga ketinggian $\pm 2 \mathrm{~cm}$, elusi dilakukan menggunakan dietil eter hingga 3 kali penuangan (Mc Carthy dan Duthie, 1962). Gambaran lapisan kolom yang digunakan untuk kromatografi kolom adalah sebagai berikut: 


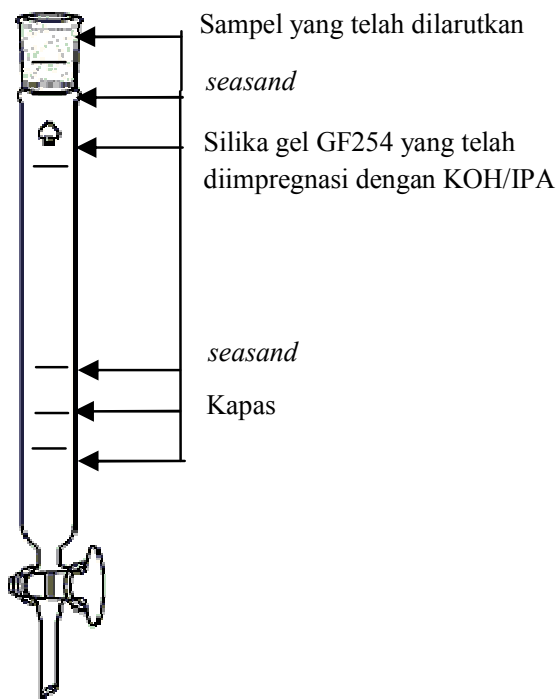

Gambar 3.1 Lapisan kolom kromatografi

Ekstrak kering yang didapatkan dilarutkan dalam campuran diklorometan dan kloroform hingga larut. Setelah kolom siap, pelarut (eluen) pertama yang digunakan adalah dietileter yang bersifat non polar. Senyawa organik yang memiliki sifat yang sama dengan dietileter dalam sampel akan ikut turun melewati silika gel dan terakumulasi sebagai fraksi netral.

Eluen kedua yang digunakan dalam proses fraksinasi kromatografi kolom ini adalah campuran dietileter dan asam format $2 \%$ yang memiliki sifat sedikit asam. Senyawa organik yang memiliki sifat yang sama dengan campuran dietileter dan asam format $2 \%$ dalam sampel akan ikut turun melewati silika gel dan terakumulasi sebagai fraksi asam.

Fraksi akhir yang tertinggal adalah fraksi polar yang didapatkan dengan menggunakan eluen kloroform:metanol:air (65\%:25\%:4\% v/v). Fraksi asam kemudiandiesterifikasi menggunakan diazomethane, ester yang terbentuk difraksinasi lebih lanjut menggunakan plat KLTP dengan $\mathrm{CH} 2 \mathrm{Cl} 2$ menghasilkan tiga fraksi yaitu monoester, diester dan poliester dengan menggunakan referensi Rf 0,9-0,5 sebagai monoester (asam stearat metil ester), Rf 0,5-0,25 sebagai diester (asam ftalat metil ester) dan Rf 0,25 - 0,05 (asam piromalitat metil ester). Fraksi netral difraksinasi lebih lanjut dengan metode KLTP menggunakan n-heksan menghasilkan fraksi alifatik ( $\operatorname{Rf} 1,0-0,9$ ) dan aromatik ( Rf 0,9-0,1 dengan referensi 1,2,5,6dibenzathracene). Sedangkan untuk fraksi polar dilakukan degradasi terlebih dahulu menggunakankatalis.

\subsection{Pemisahan Fraksi Netral}

Pemisahan terhadap fraksi netral bertujuan untuk mendapatkan fraksi alifatik, aromatik, keton, alkohol dan polar menggunakan metode kromatografi lapis tipis (KLTP). Adsorben yang digunakan adalah Silika gel GF254 sebagai fasa diam dan beberapa pelarut organik sebagai fasa gerak. Pemisahan pertama terhadap fraksi netral adalah dengan menggunakan fasa gerak diklorometan untuk mendapatkan fraksi hidrokarbon, keton, alkohol dan polar diklorometan. Langkah pertama yang dilakukan adalah fraksi netral yang telah kering dilarutkan dalam diklorometan. Siapkan plat KLTP 20 × $20 \mathrm{~cm}$ dengan ketebalan 0,25 $\mathrm{cm}$ yang telah dipreparasi dan diaktifasi. Fraksi netral yang telah dilarutkan dalam diklorometan ditotolkan disepanjang garis awal yang telah dibuat pada plat KLTP. Disamping itu diklorometan dijenuhkan dalam chamber (ruang elusi). Setelah fraksi netral telah ditotolkan pada plat, langkah selanjutnya plat tersebut dimasukkan dalam chamber hingga proses elusi mencapai garis akhir yang telah dibuat. Setelah elusi telah berakhir, plat diambil dari chamber 
dan didiamkan hingga kering. Plat yang telah kering ditandai dengan pensil sesuai $\mathrm{Rf}$, yaitu 00,1 untuk polar diklorometan ; 0,1-0,4 untuk fraksi alkohol; 0,4-0,8 untuk fraksi keton dan 0,81,0 untuk fraksi hidrokarbon. Berikut gambaran plat KLTP untuk fraksinasi fraksi netral:

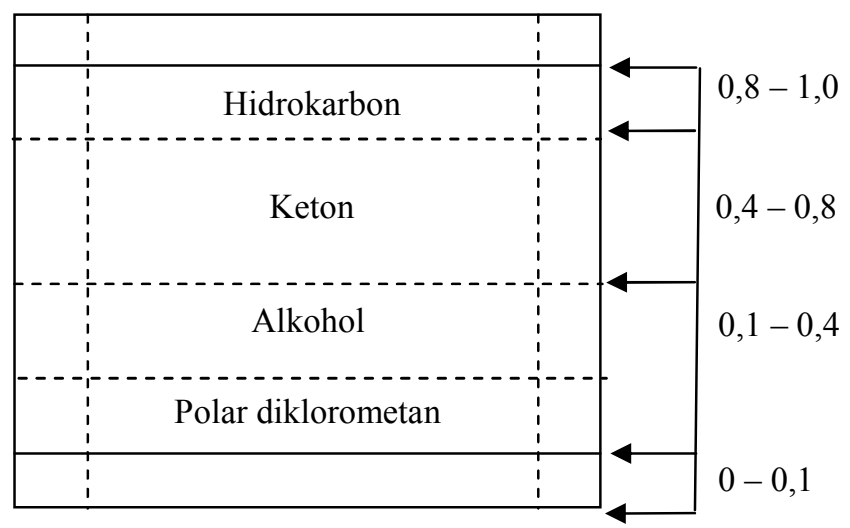

Gambar 3.2 Rf fraksinasi KLTP fraksi netral

Setelah proses elusi silika gel yang mengandung fraksi alifatik, aromatik dan polar nheksana diekstrak menggunakan corong tulip dengan pelarut diklorometan seperti langkah yang sebelumnya dilakukan terhadap fraksi hidrokarbon, keton, alkohol, dan polar diklorometan. Proses ekstraksi ini menghasilkan fraksi kering alifatik, aromatik, dan polar nheksana dalam vial. Pada penelitian ini dianalisis fraksi aromatik untuk mendapatkan informasi asal-usul, lingkungan pengendapan dan tingkat kematangan minyak.

\section{Hasil Dan Pembahasan}

Hasil analisa KG-SM terhadap fraksi aromatik minyak mentah Juwata Tarakan, Kalimantan Utara, ditunjukkan oleh kromatogram yang tertera pada Gambar 4.1 berikut :

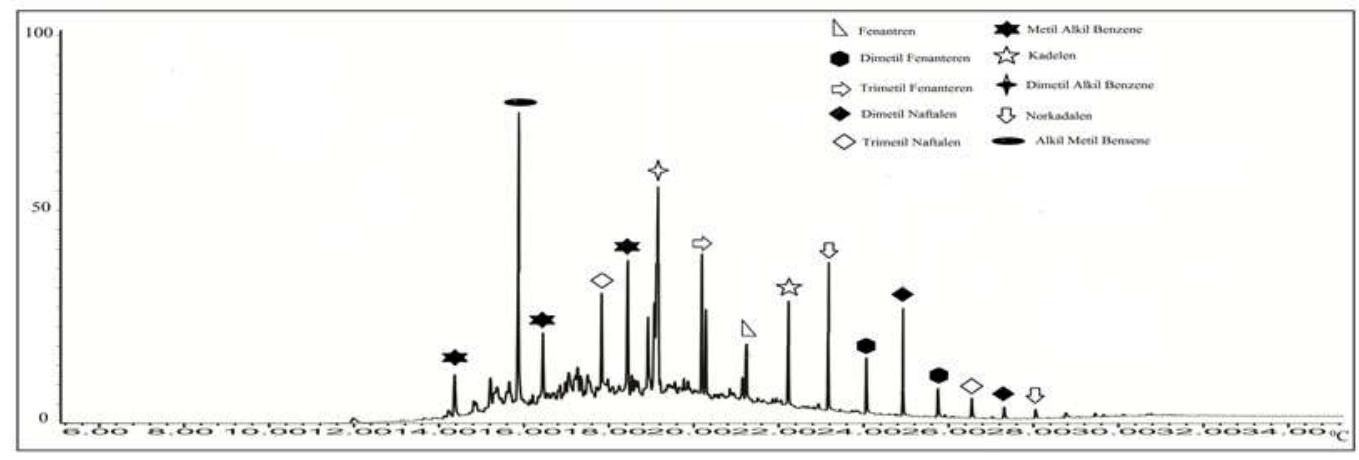

Gambar 4.1 Kromatogram total fraksi Aromatik minyak mentah Juwata Tarakan, Kalimantan Utara dengan kondisi operasi alat meliputi temperatur program $40^{\circ} \mathrm{C}$ (ditahan 2 menit), $40-100^{\circ} \mathrm{C}\left(10^{\circ} \mathrm{C} /\right.$ menit $), 100-290^{\circ} \mathrm{C}$ dengan laju $4{ }^{\circ} \mathrm{C} /$ menit ditahan selama 10 menit

Pada kromatogram total fraksi aromatik yang dihasilkan beberapa senyawa biomarka antara lain alkil benzene, naftalena, fenantren dan kadalen yang diuraikan pada fragmentogram berikut: 


\section{Senyawa Alkil Benzena dan Turunanya}

Keberadaan senyawa aromatik alkil benzena dan turunanya pada fraksi aromatik diidentifikasi berbeda-beda berdasarkan fragmentogram $\mathrm{m} / \mathrm{z} 105$ (alkil metil benzena), $\mathrm{m} / \mathrm{z} 119$ (dimetil alkil benzena) dan m/z 133(trimetil alkil benzena) ditunjukkan pada Gambar 4.2

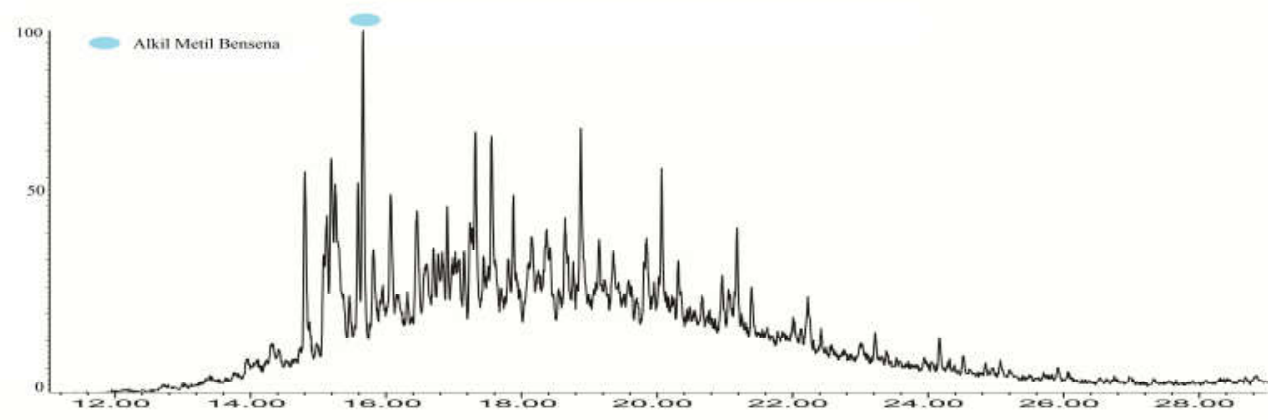

Gambar 4.2 Fragmentogram m/z105 senyawa aromatik alkil metil benzen hidrokarbon aromatic minyak menta Juwata Tarakan, Kalimantan Utara dengan kondisi operasi alat meliputi temperatur program $40^{\circ} \mathrm{C}$ (ditahan 2 menit), $40-100^{\circ} \mathrm{C}\left(10^{\circ} \mathrm{C} / \mathrm{menit}\right)$, $100-290^{\circ} \mathrm{C}$ dengan laju $40 \mathrm{C} /$ menit ditahan selama 10 menit.

Minyak mentah Juwata Tarakan, Kalimantan Utara terletak pada jumlah metil yang tersubsitusi dalam benzene. Biomarka alkil benzena telah diteliti oleh Zegouah (1999) yang melaporkan kontribusi bahan organik berasal dari turunan pegiastur alganean. Distribusi senyawa hidrokarbon aromatik ini indikasi sebagai hasil pirilosis kemungkinan merupakan turunan asli dari fenilalanin yang merupakan bahan penyusun protein. Distribusi senyawa tetrametil benzena dalam sampel minyak bumi menginformasikan terjadinya perembesan air dari kandungan sulfat dari zona fotik selama proses deposit dari minyak bumi yang memungkinkan pertumbuhan dari bakteri Chlorobiaceae (Sun dkk, 2003). Hasil kajian dan identifikasi biomarka alkil benzena maka diperkirakan terdapat masukan dari bakteri Chlorobiaceae pada pembentukan bahan organik minyak mentah Juwata Tarakan, Kalimantan Utara.

\section{Senyawa Turunan Naftalena}

Kehadiran turunan senyawa naftalena pada fraksi aromatik diidentifikasi berdasarkan fragmentogram m/z156 dan m/z170 yang ditunjukkan pada Gambar 4.3

IntensitasRelatif (\%)

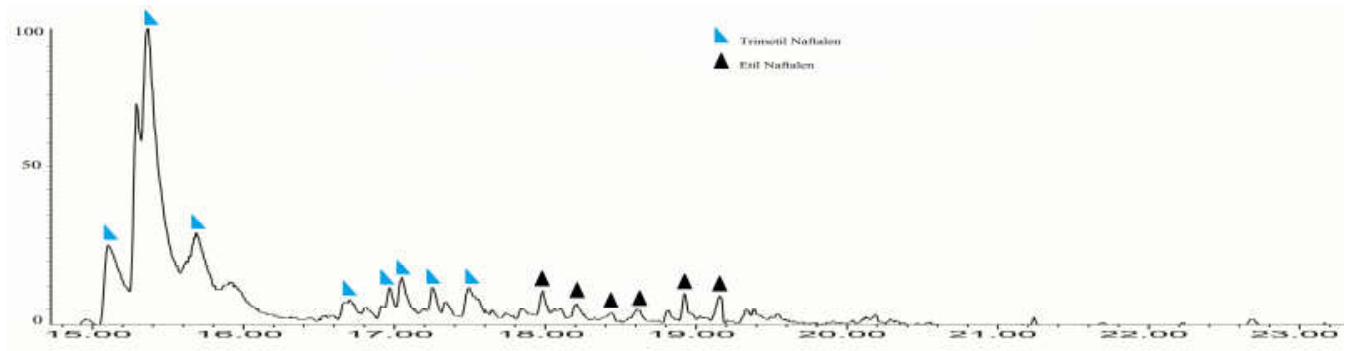

Gambar 4.3 Fragmentogram senyawa turunan naftalena fraksi hidrokarbon aromatik minyak mentah Juwata Tarakan, Kalimantan Utara dengan kondisi operasi alat meliputi temperatur program $40^{\circ} \mathrm{C}$ (ditahan 2 menit), $40-100^{\circ} \mathrm{C}\left(10^{\circ} \mathrm{C} /\right.$ menit), 100 $290^{\circ} \mathrm{C}$ dengan laju $4^{\circ} \mathrm{C} /$ menit ditahan selama 10 menit. 
Keberadaan senyawa naftalena dan turunannya memberikan informasi asal usul bahan organik dan indikator kematangan sampel geologi. Petunjuk kematangan tersebut diperlihatkan Gambar 4.31, dimana pola sebaran senyawa trimetil naftalena dapat menunjukan kematangan sampel geologi (Arsen, 1999). Asal usul bahan organik biomarka senyawa naftalena ini terlihat pada penelitian (Widodo dkk, 2009) melaporkan bahwa naftalena dan turunanya berasal dari hasil depolimerisasi senyawa polikadena yang terkandung di dalam resin damar dipterocarpaceae family angyospermae. Hal ini dibuktikan senyawa naftalena sebagai hasil cracking senyawa kadinana yang merupakan produk utama dari polikadinena pada tahap katagenesis. Pada tahap tersebut terjadi proses depolimerisasi dan aromatisasi polikadinena karena panas dan temperatur tinggi (Radke dkk, 1994). Selain itu, produk lain dari depolimerisasi dan aromatisasi tersebut (terlihat pada Gambar 4.20), berupa senyawa, bikadinana dan senyawa aromatik (Eudsmana).Vegetasi tanaman jenis angyospermae Dipterocarpacaceae dapat tumbuh pada hutan hujan tropis di zaman Miosen (Dutta dan Mallick, 2010).

Berdasarkan proses terbentuknya biomarka naftalena dari hasil depolimerisai resin damar, maka diperoleh gambaran bahwa pembentukan minyak mentah Juwata Tarakan, Kalimantan Utara terdapat masukan bahan organik dari keluarga angyospermae Dipterocarpacaceaepada zaman Miosen. Hal ini diperkuat kajian dan identifikasi sebaran biomarka anatara lain : bikadina dan eudesmana yang menginformasikan terdapat kontribusi pembentukan bahan organik berasal dari tanaman Dipterocarpacaceae sehingga mempertegas adanya dominasi kontribusi bahan organik dari wilayah darat (terrestrial). Informasi lain yang diperoleh dari sebaran trimetil naftalena pada sampel memiliki pola yang serupa (Gambar 4.32) yang mengindikasikan minyak mentah Juwata Tarakan dalam kondisi matang. Tahap pembentukan minyak diperkirakan pada zaman Miosen.

\section{Senyawa Turunan Fenantrena}

Indikasi biomarka senyawa hidrokarbon aromatik selanjutnya adalah senyawa fenantrena dan turunannya dengan mengelusidasi fragmentogram, m/z 206 dan m/z 220 . Fragmentogram tersebut diekstraksi dari kromatogram total dan hasilnya dtunjukkan pada Gambar 4.4.

\section{Intensitas Relatif (\%)}

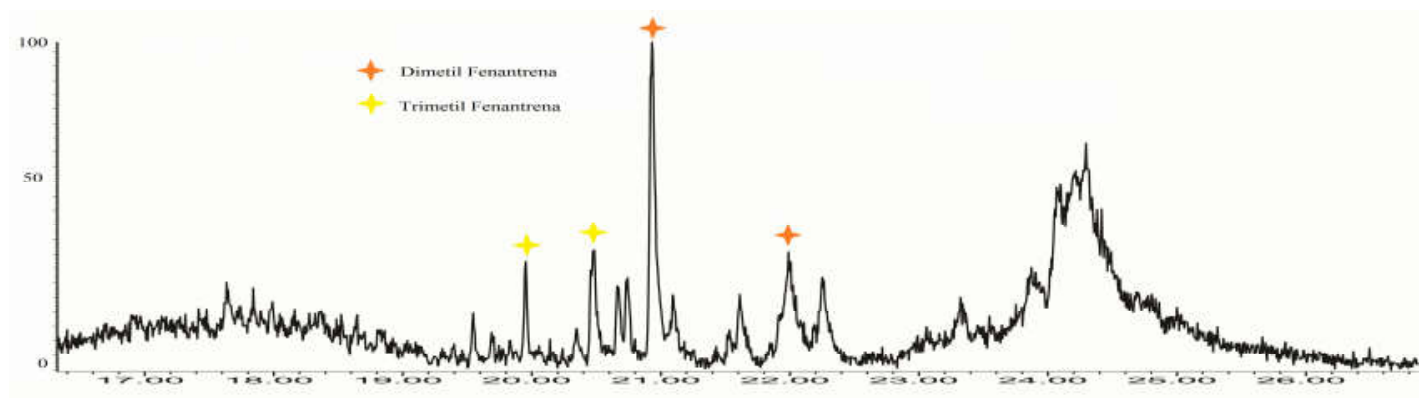

Gambar 4.4 Fragmentogram senyawa turunan fenatrena fraksi hidrokarbon aromatik minyak mentah Juwata Tarakan, Kalimantan Utara dengan kondisi operasi alat meliputi temperature program 400C (ditahan 2 menit), 40-1000C (100C/ menit), 1002900C dengan laju 40C/menit ditahan selama 10 menit.

Distribusi sebaran hidrokarbon aromatik teralkilasi, contohnya fenantrena merupakan sumber umum yang terdapat dalam minyak bumi dan sedimen, selain itu rasio isomer metil fenantrena memberikan informasi mengenai kematangan termal pada batuan sumber (source rock) (Eglinton dkk, 2006). Pada isomer tertentu pada senyawa DMP dan TMP dapat 
dihubungkan dengan asal usul bahan organik, hal ini diperlihatkan dengan keberadaan senyawa 2,6-DMP mengindikasikan adanya masukan bahan organik dari wilayah terrestrial, hal ini menandakan masuknya tanaman darat (Budzinki dkk,1995). Pada penelitian oleh Widodo dkk (2009) yang melaporkan senyawa fenantrena dan turunannya merupakan produk diagenesis dan tanaman konifer family Gymnospermae. Tahap pembentukannya dilaporkan oleh Simoneit dkk (1986), dimana keberadaan senyawa fenantrena dan turunannya berasal dari asam abitat yang mengalami aromatisasi. Selain itu juga dapat berasal dari isomer asam abietat, yakni asam pimarat. Keberadaan senyawa fenantrena ini memberikan gambaran bahwa vegetasi tanaman conifer hidup di zaman Miosen (Widodo dkk, 2009).

Hasil kajian dan identifikasi biomaraka fenatrena, maka dapat disimpulkan distribusi senyawa fenatrea dan turunannya memberikan informasi kontribusi bahan organik dari konifer family Gymnospermae.

\section{Senyawa Kadalena Dan Turunannya}

Analisi kromatografi gas-spektrokopi massa untuk biomaraka senyawa turunan kadalena dengan menganalisa fragmentogram m/z 169 dan m/z 183. Fragmentogram m/z 169 dan $\mathrm{m} / \mathrm{z} 183$ diiekstraksi dari kromatogaram total dan hasilnya ditunjukkan pada Gambar 4.5

Intensitas Relatif (\%)

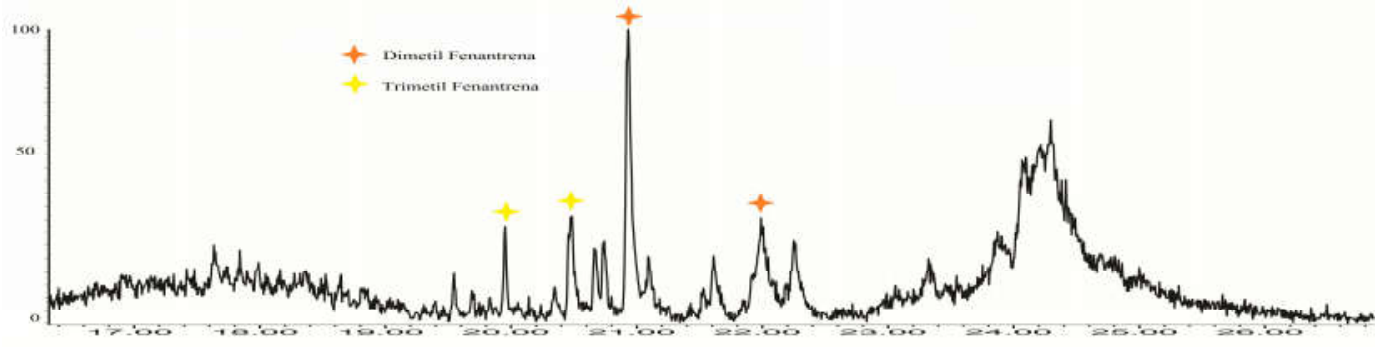

Gambar 4.5 Fragmentogram senyawa kadalena dan turunannya fraksi hidrokarbon aromatik minyak mentah Juwata Tarakan, Kalimantan Utara dengan kondisi operasi alat meliputi temperature program $400 \mathrm{C}$ (ditahan 2 menit), 40-1000C $(100 \mathrm{C} / \mathrm{menit})$, 100-2900C dengan laju 40C/menit ditahan selama 10 menit.

Puncak-puncak fragmentogram Gambar 4.5 hasil eksploitasi tersebut menunjukkan terdeteksinya masing-masing ion molekuler m/z 184,198 yang mengindikasikan derajat ketidakjenuhan sebesar 7 berarti memiliki 5 ikatan rankap dan 2 siklik. Hal ini sesuai dengan karakteristik senyawa kadalena dan turunannya yang tersusun dari 2 cincin benzena. Bukti lain dari senyawa kadalena dan turunanya ialah terdeteksinya fragmen ion 183/184 yang menindikasikan terlepasnya fragmen $(\mathrm{C} 15 \mathrm{H} 18)+$. Selain itu, hasil eksplorasi spektrum massa menunjukkan fragmen ion yang terbesar pada $\mathrm{m} / \mathrm{z} 155,169$ dan 183 , dimana pola fragmentasi ini merupakan karakterisitik senyawa kadalena dan turunannya, hasil eksploitasi spektrum massa dilakukan diperoleh sebaran senyawa 2 isomer narkodalena dan 1 isomer kadalena.

Keberadaan senyawa narkodalena memiliki kerangka dasar yang serupa dengan senyawa kadinana, dimana prekursor utama dari senyawa ini berasal dari minyak atsiri dan resin tanaman tingkat tinggi. Biomarka ini memiliki struktur yang sama dengan senyawa kadalena sebagai petunjuk masukan bahan biologis dari tanaman tinggi tinggi, byrophita dan fungi (Sing dkk, 1994) . Petunjuk prekursor tanaman tingkat tinggi pun ditunjukkan pada senyawa kadalena dan turunanya, dimana senyawa kadalena memiiki struktur yang serupa dengan biopolimer resin tumbuhan tropis Angyospermae (Brocks dan Summons, 2003). Hal ini dibenarkan oleh Radke dkk (1994) melaporkan senyawa biomarka kadalena memberikan informasi bahwa adanya masukkan bahan biologis yang berasal drai turunan resin fosil. Hal ini dijelaskan mengenai jalur pembentukkan senyawa kadalena dengan terlepasnya kadinol dari kerogen yang diikuti 
aromatisasi yang mengindikasikan adanya masukan dari wilayah terrestrial pun dilaporkan dalam penelitian yang dilakukan oleh Dutta dan Mallick (2010).

Hasil kajian dan identifikasi biomarka narkodalena) dan kadalena menunjukkan bahan organik minyak mentah Juwata Tarakan, Kalimantan Utara didominasi dari vegetasi tanaman Dipetrocarpaceae (Angyospermae) pada zaman Miosen. Hal ini diperkuat pada penemuan biomarka sebelumnya, seperti: bikadinana, eudesmana dan senyawa naftalena dan turunanya yang diperkirakan adanya kontribusi bahan organik dari tanaman Dipetrocarpaceae pada minyak mentah Juwata, Tarakan. Selain itu, pembentukkan bahan organik sampel minyak mentah disinyalir didominasi dari wilayah terrestrial. Tahap pembentukkan minyak zaman Miosen.

\section{Kesimpulan}

Kajian biomarka fraksi aromatik yang diperoleh antara lain:senyawa alkil benzena tersubstitusi, naftalena, fenatrena dan kadalena yang memberikan informasi bahwa minyak mentah Juwata Tarakan, Kalimantan Utara didominasi bahan organik yang berasal dari tumbuhan tingkat tinggi dari wilayah terrestrial. Bahan organik darat tersebut salah satunya didominasi jenis tanaman Dipterocarpaceae Angyospermae, selain masukan jenis tanaman angyospermae terdapat masukan tanaman darat lain yaitu tanaman Gymnospermae (konifer) dan masukan bahan organik dari prekursor biogenik seperti bakteri. Lingkungan pengendapan minyak ini bersifat oksidatif, tingkat kematangan tinggi maka minyak mentah Juwata Tarakan, Kalimantan Utara layak dilakukan pengesplorasian selanjutnya.

\section{DAFTAR PUSTAKA}

Alexander dan James Lucky, (1983), Identificationof the Bicyclic Sesquiterpenes Drimane and Eudesmanein Petroleum.

Burhan, R. Y. P., Trendel, J. M., Adam, P., Wehrung, P., Albrecht, P. dan Nissenbaum, A. (2002), "Fossil Bacterial Ecosystem at Methane Seeps: Origin of Organic Matter from Be'eri SulfurDeposit, Israel”, Geochimica et Cosmochimica Acta, Vol. 66, No. 23, hal. 4085-4101.

Christian Gordy Dalima, (2004), Analytical Chemistry., John Wiley \& Sons, Inc., Washington DC.

Duan, Y, (2000), "Organic Geochemistry of Recent Marine Sediments From Nansha SeaChina" Org. Geochem, 31, 159-167

Dutta, S dan Mallick, M, (2010), " Chemical composition and paleobotanical origin of Moicene resin from krela-Konka Coast, wastern India". J Earth Syst. Science 119, 711-716.

Elen, (2008), Proses Terbentuknya Cekungan Tarakan Skripsi. Universitas Indonesia.

Farhaduzzaman, M., Abdullah W. H. dan Islam M. A. (2012), "Depositional environment and hydrocarbon source potential of the Permian Gondwana crude oil from the Barapukuria Basin,Northwest Bangladesh",InternationalJournal of Coal Geology.9091, 162-179

Hardianto Yoga (2014), filosofi cekungan Tarakan, Kalimantan Utara

Hunt, J. M, Kvenvolden, K. A,(1994),"Early Development in Petrolium Geochemistry". Org. Geochem., 33, 1025-1052.

Killops, S. D., Killops, V, J., (1994), “ An Introduction to Organic Geochemistry”, Jhon Wiley \& Sons, Inc., New York.

Harish, (2014), "The formation process of crude oil in the basin" fuel 53, 100-250

Mahaboob Alam dan M. J. Pearson (1993), "Bicadinanes In Oils From The Surma Basin Bangladesh", Department Of Geology And Petroleum Geology, The University, Marischal College. 15, 461-464.

McCarthy, R. D. dan Duthie A. H. (1962), A rapid quantitative method for the separation of free fatty acids from other lipids. J Lipid Res.3, 117-119. 
Moldowan, J.M.,Fago,F.J., Carlson, R.M.K., Young,D.C.,Duyne, G. V.,Clardy, J., Schoell, M., Pillinger, C.T.,Watt, D. S.,(1991), Rearranged Hopanes in Sediments and Petroleum", Geochim. et Cosmochim. Acta, 55, 3333- 3353.

Pavia, D. (2009), Introcudtion to Spectroscopy, Fifth Edition, Western Washington University, Washington.

Peters, K.E., Moldowan, S.M., (1993), "The Biomarkers Guide Interprenting $\quad$ Molecular

Fossil in Petroleum and Ancient Sediment", Prentice Hall. Inc, New Jersey

Radke, M., dan Rullkotter, J., Vrienf vriend, S.P. (1994), "Distribution of naphatalenes in crude oils from java sea : source maturation effects." Geoemihimica et cosmochimica Acta 58, 3675-3689.

Sun, Y.G., dan Xu S.P., Lu, H., Cuai P.X. (2003), "Source Facies of the paleozonic Petroleum System in the Tabei Uplift,Tarim Basin, NW China: Implications from Aryl Isoprenoids in crude oils". Elsevier Science Ltd 34, 629-634

Tissot, P.B. dan Walte, H.D. (1984), Petroleum Formation and Occurance $2^{\text {nd }}$ edition. Berlin : Spinger-Verlag.

Ilham, (2014), "peranan energy fosil minyak bumi", hal. 1-7.

Yuanita, (2007), biomarka hidrokarbon alifatik Sedimen laut arafuru. Akta kimia Indonesia 2. 99-102

Yusriani. (2009), Sidik jari biomarker minyak bumi wilayah Indonesia bagian barat skripsi. Universitas Indonesia, Jakarta.

Tissot, P.B. dan Walte, H.D. (1984), Petroleum Formation and Occurance $2^{\text {nd }}$ edition. Berlin : Spinger-Verlag.

Widodo, S., dan Bechtel A., Anggayana K., Puttmann W. (2009), "Recontruction of floral changes during deposition of the Miocene Embalut from Kutai Basinns, , Mahkam Delta, East Kalimantan, Indonesia by use of aromatic hydrocarbon composition and stable carbon isotop ratios of organic matter". Organic Geochemistry 40, 206-218 